\title{
BALANCED SCORE CARD AND ORGANISATIONAL SUCCESS OF SMES IN RIVERS STATE
}

\author{
Joseph-Wakama Josephine \\ Department of Management, University of Port Harcourt Business School \\ B. Chima Onuoha \\ Department of Management, University of Port Harcourt
}

Article DOI: https://doi.org/10.36713/epra5352

\begin{abstract}
The impact of the balance scorecard on the success of small and medium-sized enterprises in Port Harcourt, Rivers State, was examined in this study. Ex Post Facto research design was adopted and data was collected in Port Harcourt, Rivers State, from annual reports and accounts of small and medium-sized enterprises. To test the hypotheses formulated with the assistance of SPSS version 25.0.0, simple regression analysis was used. On this basis, the research revealed that the company's Growth and Learning perspective, consumer perspective and business process outlook had an impact on the return on small and medium-sized businesses' assets in Port Harcourt, Rivers State. At the same time, criterion variables (after tax profits) and predictor variables (growth and learning, clients and perspectives on business processes) have a statistically significant effect on organizational success. The study therefore suggested, among other things, that; small and medium scale firms should consider the issue of production costs and must improve their cost minimization strategy. Also, consumers should be more involved in decision-making to make them feel valued and continue to provide the firm with business rather than competition.

KEYWORDS: Balanced Scorecard, financial performance and small and medium scale firms.
\end{abstract}

\section{INTRODUCTION}

In recent years, the Balance Score Card (BSC) has acquired considerable importance as a strategic management tool that allows firms to align their business activities with the vision and strategy of the firm and improve their overall performance (Kaplan \& Norton, 2005). In 1992, Robert Kaplan and David Norton introduced the BSC concept for the first time. Since the last few years, Saudi businesses have been implementing this instrument, although little information is available about its impact on their business success (Bassioni, Price, \& Hassan, 2004). The BSC provides a logical link, according to Kaplan and Norton, between the Vision, Mission and Strategic Objectives and the desired results in terms of consumer and stakeholder needs, financial, internal processes and capacity building (Growth and Learning) linked through relationships of cause and effect (Kaplan \& Norton, 2015).

A carefully chosen set of quantifiable measures derived from the strategy of the firm, the Balanced Score Card (BSC) is a management tool with three main components: the measurement system, the strategic management system and the communication system (Bremser \& Barsky 2004). For this reason, in modern times, the focus on measuring non-financial success is gaining ground and the business community is increasing its support. A balanced scorecard is a success measurement tool that has become more popular in practice and in literature. Arben, Skender, 


\section{SJIF Impact Factor: 7.001| ISI I.F.Value:1.241| Journal DOI: 10.36713/epra2016 ISSN: 2455-7838(Online) EPRA International Journal of Research and Development (IJRD)}

Arbana and Muhamet (2016) argued that to determine the success level of corporations, this model considers financial indices and non-financial indices necessary. Success measurements from these perspectives are included in the Balanced Scorecard: financial, client, internal business processes, Growth and Learning.

Supporters of the balanced scorecard argue that, in order to achieve success in financial measurement, the first non-financial measures have to be taken (Davis \& Albright 2004). Therefore, to determine whether the focus on non-financial measures actually leads to better profit margins and better firm's success using a balanced scorecard, empirical research is necessary.

Researchers claim that a paradigm shift has occurred from a traditional approach to measurement of financial success to an approach that integrates both financial and non-financial measures (Atkinson \& Kaplan, 2003). Firms have a variety of objectives and objectives and it is therefore more likely that firm's progress towards all of these objectives and objectives will be effectively assessed by a single measure or even a number of measures of the same type.

In the meantime, virtually all businesses use some measure of revenue to assess success. In relation to consumer satisfaction rates, product defect rates, market time and environmental social responsibility, firms have set targets. Such goals are not measured by revenue directly. Firms that produce inferior products, deliver late, abuse the environment or clients that are generally dissatisfied will lose market share and be forced out of business (Spraakman, 2005).

Research has shown that intangibles are the strongest drivers of competitive achievement, especially intellectual property, innovation and quality. They should be measured, since what is measured is done and these variables are important (Kairu, Wafula, Okaka, Odera \& Akerele, 2013).

Studies comparing the financial success of the two sister concerns of the UK-based electric wholesale chain have shown that with respect to its sister concern that BSC has not implemented, the company implementing BSC has demonstrated better financial success (Neely, 2008). BSC's impact on the alignment of strategic goals and success reporting was studied by Iselin, Mia, \& Sands (2008). The use and problems of BSC as a success measurement tool were discussed by Muhammad (Muhammad, 2010). Results show that managers involved in the selection of strategic initiatives see these initiatives as more effective than managers who do not participate in the selection process of the strategy. As a result, BSC indirectly affects corporate strategies' implementation and success (Tayler, 2007).
Strategic plans have been developed in the light of these firms, particularly in small and medium scale firms, but are not put to use because they seem to have more urgent problems to deal with in the day-to-day running of the organisation. Therefore, this situation justifies the use of the Balanced Scorecard (BSC) as a critical step in the strategic process being implemented.

This situation calls for the implementation of more policies that would increase the manufacturing company's success. The aim of this study is therefore to assess the effect of the balance-sheet scorecard on the firm's success of small and medium scale firms in Nigeria with specific reference to: Growth and Learning Perspective, Costumers Perspective, Internal Business Process of small and medium-sized enterprises quoted on the Nigerian stock exchange with a view to providing solutions to its bar success.

The aim of this study was to assess the impact of small and medium-sized enterprises' firm's success on the balance scorecard in Port Harcourt, Rivers State. The specific objectives are set out below.:

1. To ascertain the implication of Growth and Learning Perspective on after tax profits of small and medium scale enterprises in Port Harcourt, Rivers State.

2. To determine the implication of Consumer Perspective on after tax profits of small and medium scale enterprises in Port Harcourt, Rivers State.

3. To evaluate the company's Business Process Perspective on after tax profits of small and medium scale enterprises in Port Harcourt, Rivers State.

\section{REVIEW OF RELATED LITERATURE Conceptual Framework Balanced Scorecards}

A balanced scorecard provides a collection of balanced success management measurements and links these measurements to a strategic success improvement initiative. Some studies have been carried out on the impact on enhanced success of the use of a balanced scorecard. As a tool for measuring business success, there is an increasing trend in the implementation of the Balance Scorecard Strategy (Davis \& Albright, 2004). It is estimated that the balance scorecard is used by some 44 percent of US firms. In general, it is perceived that in developed economies where competition is high, the balanced scorecard is mostly used. The Balanced Scorecard can be defined as a tool for success management that facilitates the translation into a tangible set of measurements of the company's vision and strategy (Arben, et al, 2016). In other words, the Balanced Scorecard (BSC) is a success measurement 


\section{SJIF Impact Factor: 7.001| ISI I.F.Value:1.241| Journal DOI: 10.36713/epra2016 ISSN: 2455-7838(Online) EPRA International Journal of Research and Development (IJRD)}

conceptualization that translates the strategy of the firm into clear goals, measures, goals and initiatives organized under four perspectives: financial, client, business processes and human resources or innovation and learning (Kassahun, 2010). In order to operate at an optimum capacity, each area perspective represents a different aspect of the business firm.

Chaudron (2003) argued that BSC is a means of: measuring firm's, business or departmental success; balancing long-term and short-term actions; balancing success measures; financial; client; internal operations; development and development of human resources systems (Growth and Learning); linking the strategy of the company to action measures. Much of the scorecard's success depends on how the measures are agreed upon, how they are implemented and how they are implemented (Bourne, 2002).

As a result, because of its business efficiency resulting from the four significant balanced perspectives, the BSC adopts the specific approach structure and components of the success measurement system, thus ensuring more profits for the company's activities (Christesen, 2008). Kaplan and Norton (2015 ) suggest that firms should articulate the objectives of time, quality, success and service while remaining sensitive to the cost of their products in order to build consumer confidence and loyalty..

\section{Perspectives of Balanced Scorecard Consumer perspective}

This perspective captures the ability of the firm to deliver quality goods and services, the effectiveness of their delivery, and overall satisfaction and consumer service. This will result from proposals for prices, quality, availability, selection, functionality, service, partnership and brand value, leading to increased consumer acquisition and retention (Gekonge, 2005). The BSC asks executives to translate their general mission statement of consumer service into specific measures reflecting the factors that really matter to consumers (Kaplan \& Norton, 1992).

Consumer concerns tend to fall into four categories: time, quality, service and success, and cost. Satisfied consumers buy a product again, talk about the product favorably to others, pay less attention to competing brands and advertising, and purchase other business products (Kotler \& Armstrong, 2004). A growing awareness of the significance of consumer focus and consumer satisfaction in any business has been shown by recent management philosophy (Chabrow, 2002; Needleman, 2003).

This perspective takes into account a company's ability to provide its consumers with quality goods and services, the effectiveness of providing those services, and addresses its consumers' concerns with a view to developing ongoing support (Zairi \& Jarrar, 2000). Here, the focus is on the clients and how to give them value. This is because the drive to monitor and retain clients loses credibility when a company loses. And, as such, without a strong client base, no company can thrive...

\section{Internal processes perspective}

The perspective of internal processes focuses, according to Gekonge (2005), on internal business outcomes that lead to financial success and satisfied consumers. Firms must identify the key business processes in which they must excel in order to meet the firm's goals and expectations of clients. To ensure that the results are always satisfactory, these key business processes are monitored. Internal processes report on the efficacy of internal procedures and processes. Consumer-based measures are important, but must be translated into measures of what the firm must do internally to meet its clients' expectations (Kaplan \& Norton, 1992). The premise behind this perception is that

Business Process Perspective focuses, according to Gekonge (2005), on internal business results that lead to financial success and satisfied consumers. It consists of measures relating to business processes such as cost and quality.

\section{Growth and Learning Perspective}

The innovative capacity, Growth and Learning perspective of a company examines the capacity of employees (skills, talent, knowledge and training), the quality of information systems (systems, databases and networks) and the implication of firm's alignment (culture, leadership, alignment and teamwork) to promote the achievement of firm's goals, according to Kaplan and Norton (1992).

In order to create long-term, sustainable growth and continuous improvement, this includes identifying the infrastructure that a company needs to develop. In order to meet the environmental challenges facing competition and to give value to its consumers, management is required to continually improve its firm's skills. Three business sources for Growth and Learning were identified by Kaplan and Norton (2000): individuals, the information system, and firm's processes. Through existing skills and potential for enhanced success, financial perspective, client and internal business processes often identify gaps in firm's structure. Through management initiatives such as investment in staff training and IT (Chytas, 2011), these gaps can be addressed. Businesses can take as 


\section{SJIF Impact Factor: 7.001| ISI I.F.Value:1.241| Journal DOI: 10.36713/epra2016 ISSN: 2455-7838(Online) EPRA International Journal of Research and Development (IJRD)}

much as their staff, so real efforts should be made to retain staff with the knowledge and information that the Growth and Learning perspective seeks to determine.

\section{Success and the Balanced Scorecard}

According to Abernathy (2000), the typical employee does not understand the strategy of the firm and, as a result, does not focus on the right things; does not know his or her personal role in the implementation of the strategy and, as a result, does what is needed, not what is needed. Firm's sub-optimization is the result of sub-firm's optimization in such a corporate environment. Frigo and Krumwiede (2000 ) suggested that the BSC could help to remedy this situation by requiring firms to engage in a number of beneficial activities. These activities outline the main strengths of the BSC.

Success measurements incorporating nonfinancial measures have been a subject of great interest throughout most of the 1990s. This is because nonfinancial measures overcome the limitations of financial success measures. "Soft" measures, such as employee satisfaction and commitment, are coming to the fore as protagonists of the business success measurement revolution, urging firms to complement their traditional financial focus with softer data. Kaplan \& Norton (1992 ) suggested that "a balanced presentation of both financial and operational measures is needed. Meanwhile, BSC translates the mission and strategy of the firm into a comprehensive set of success measures that provide a framework for a strategic measurement and management system (Kumari, 2011).

\section{Review of Previous Studies}

In and around the world, various studies have been carried out on the Balance Scorecard. The impact of the Balanced Scorecard (BSC) on the success of Kenyan firms in the service sector was determined by Kairu, Wafula, Okaka, Odera and Akerele (2013). A survey research design of 200 firms providing services was used. In order to collect primary data, semistructured questionnaires were used that were analyzed through descriptive statistics. The study found that in measurement systems, non-financial criteria are as important as financial criteria and lead to superior results when both measures are integrated into the system.

Braam and Nijssen (2004) examined how to use the Balanced Scorecard (BSC) using regression analysis to regress over business success over the past three years and a subjective non-financial measure effectively adopted step-model. Dutch firms' empirical evidence suggests that the use of BSC will not automatically improve the success of the company, but that the manner of its use matters.

In their study on Balanced Scorecard Success of Hotels, Kala and Bagr (2014) were conducted in different accommodation facilities in some selected tourist towns in the mountainous state of Uttarakh and India. The study results indicate that the study area's hospitality managers need to identify and incorporate the right set of financial and non-financial success measures and link them to the goals of their firm.

The use of BSC characteristics among firms listed on the Stock Exchange of Thailand (SET) was determined by Wasatoin (2013). To test the proposed hypotheses, a simple regression analysis was employed. The results of the regression analysis showed that top management support was a key influence factor for each BSC attribute to be implemented.

The implication of the predictor variables (Balanced Scorecard Dimensions) on the criterion variables (ATP and ROE) was investigated by Noor, Mseden and Mohammad (2015) using Jordanian industrial firms listed on the Amman Stock Exchange for a period of five years (2008-2012). The results showed that each of the dimensions of the balanced scorecards (internal business processes, innovation and growth and consumer) had a significant positive impact on the ATP and ROE financial success drivers. The implication of the balanced scorecard on improving the success and profitability of the implementing firms was assessed by Arben, Skender Arbana and Muhamet (2016). Using secondary data, research was carried out; narrative analysis for this study was adopted. This research showed that the balanced scorecard helped improve the success and profitability of the firms that adopted the model. Hoque and James (2000) examined the connection between firm's success improvement and a balanced scorecard. In Australia, a survey of 66 small and medium scale firms was carried out. Their results indicate that larger firms, as opposed to small ones, use the model more. In addition, the findings show a very positive link between the use of measurements and superior success. Malina and Selto (2001 ) identified large divisions of a large manufacturing company with the objective of evaluating the effectiveness of the model in order to communicate strategic objectives and as a management control tool. It was found that there were appropriate opportunities for the model to develop and communicate the business strategy. They have also identified evidence between the operation of balanced scorecard control and the level of success enhancement.

The degree to which the use of the model improves the financial success of bank branches in the USA has been studied by Davis and Albright (2004). 


\section{SJIF Impact Factor: 7.001| ISI I.F.Value:1.241| Journal DOI: 10.36713/epra2016 ISSN: 2455-7838(Online) EPRA International Journal of Research and Development (IJRD)}

Their study offers the opportunity to suggest that the model can be used to enhance financial success after the results show that branches that have used the model have surpassed those that have not been measured on a standard basis. The relationship between relational capabilities and a balanced scorecard in Nigerian small and medium scale firms was determined by Lasisi, Olajide, Hasan and Shodiya (2014). The result of the study confirms that in Nigerian small and medium scale firms there is a statistically significant relationship between relational capabilities and a balanced scorecard.

As a success evaluation tool, Akram and Tariq (2014) examined the extent of BSC adoption and implementation among Palestinian listed corporations. Financial and other non-financial (consumer, internal business process, and Growth and Learning) perspectives were used. One sample t-test method has been used to test hypotheses and findings have shown that most Palestinian firms use BSC either fully or partially in their assessment process.

Ibrahim and Upendra (2016) discuss the impact on the financial success of listed firms in the Kingdom of Saudi Arabia of the implementation of the Balanced Scorecard (BSC). For this study, a sample of 57 firms from various business sectors was taken. For this comparison, annual success data for key financial parameters were taken over a five-year period and the average success for these parameters was compared using t-statistics. The study found that BSC's adoption significantly improves revenue growth, while other financial parameters such as Net Margin, Current Ratio and Operating Cash Flow / Net income do not have much impact.

Ondieki (2017) performed on Popo Road off Mombasa Road in South C at the Kenya Bureau of Standards (KEBS), a state corporation located in the southern part of Nairobi County. The study used a cross-sectional descriptive design. Using a selfadministered questionnaire, data for the study was collected. Before the questionnaire was administered, informed consent was sought. To analyze data, IBM SPSS ${ }^{\circledR}$ version 23 was used. Tables and bar charts were used to present the results of the analysis. In order to establish the relationship between criterion variable, success and predictor variables, bi-variate analysis and Pearson's product-moment correlation co-efficient (r) were used. The results of this study showed that the four perspectives under study, namely finance, internal business, innovation and consumer, have an impact on the firm's success and, despite the lack of profitability, there has been good firm's success overall at KEBs.

Studies such as; Edwin (2004); Kairu, Wafula, Okaka, Odera and Akerele (2013); Braam \& Nijssen
(2008); Kala and Bagr (2014; Wasatoin (2013); Noor, Mseden \& Mohammad (2015); Zuriekat, Salameh and Nrawasdeh (2015); Arben, Skender Arbana and Muhamet (2016); Hoque and James ( 2000); Ibrahim and Upendra (2016) etc. have carried out most of the studies of this nature in foreign countries. Few of those conducted in Nigeria were not in financial success; Lasisi, Olajide, Hasan, \& Shodiya (2014 ) examined the relationship between relational capabilities and balanced scorecard in Nigerian small and medium scale firms in their study. As such, this study was set up to assess the impact of the firm's success of the Balanced Score card on small and medium-sized businesses in Port Harcourt, Rivers State.

\section{METHODOLOGY Research Design}

Ex-post-fact research design has been adopted for this study. Ex-post facto determine the factors associated with certain occurrences, conditions, events or behaviors by analyzing past events or existing data for possible incidental factors (Orji, 1996). This is appropriate because the objective of the study is to measure the relationship between one variable and another, in which the variables involved are not manipulated by the researcher..

This study used twenty small and medium scale enterprises quoted on the Nigerian Stock Exchange for seven years study periods.

\section{Method of Data Analysis}

To test the formulated hypotheses, the study used simple regression analysis to test the balanced score cards (BSC) perspectives firms. Independents variables include Growth and Learning perspective, consumers' perspective and internal perspective while criterion variable is after tax profits.

\section{Model Specification}

The following logistic regression model will be used to test the following hypotheses:

In order to determine the implication of the firm's success of the balanced scorecard, the functional model formulated for this study is expressed as;

$$
\begin{aligned}
& \mathrm{ATP}=\beta 0+\beta 1 \mathrm{LNG}+\beta 2 \mathrm{CSG}+\beta 3 \mathrm{BPP}+\text { et....... } \\
& \mathrm{ATP}=\beta 0+\beta 1 \mathrm{LNG}+\text { et } \ldots \ldots \ldots \ldots \ldots \ldots \ldots \ldots \ldots . . . \mathrm{ii} \\
& \mathrm{ATP}=\beta 0+\beta 2 \mathrm{CSG}+\text { et } \ldots \ldots \ldots \ldots \ldots \ldots \ldots \ldots \ldots \text {.iii } \\
& \mathrm{ATP}=\beta 0+\beta 3 \mathrm{BPP}+\text { et } \ldots \ldots \ldots \ldots \ldots \ldots \ldots \ldots \ldots \text { iv }
\end{aligned}
$$




\section{EPRA International Journal of Research and Development (IJRD) \\ Volume: 5 | Issue: 10 | October 2020 \\ - Peer Reviewed Journal}

Where:

$\mathrm{ATP}=$ After tax profits

$\mathrm{LNG}=$ Growth and Learning Perspective

CUSP $=$ Consumer perspective

$\mathrm{BPP}=$ Business process perspective

et $=$ Error Term

Description of Variables

Criterion variable: Financial success proxy by After tax profits (ATP).
Predictor variables: Growth and Learning Perspective $=$ Measured as Employee Capital Revenue/Cost, Consumer Perspective $=$ Measured as Percentage in Consumers sales growth, Internal Business Perspective $=$ Measured as (inventories + Trade Receivables)/Total Assets.

\section{DATA PRESENTATION AND}

\section{ANALYSIS}

Data Presentation (See appendix)

Test of Hypotheses

Hypothesis one

Ho: Growth and Learning perspective does not affect after tax profits of small and medium scale enterprises in Port Harcourt, Rivers State.

Table 1: Model Summary

\begin{tabular}{|c|r|r|r|r|}
\hline Model & R & R Square & Adjusted R & $\begin{array}{c}\text { Std. Error of } \\
\text { the } \\
\text { Estimate }\end{array}$ \\
\hline 1 & $.877 \mathrm{a}$ & .769 & .723 & 21.78662 \\
\hline
\end{tabular}

a. Predictors: (Constant), LNG

Table 2: ANOVA ${ }^{a}$

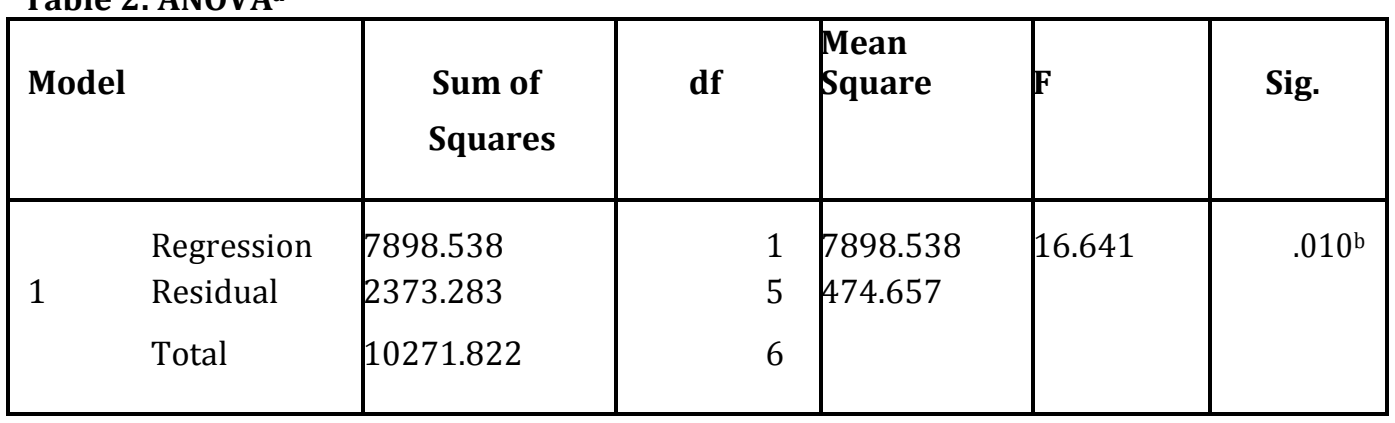
a. Criterion variable: ATP
b. Predictors: (Constant), LNG 


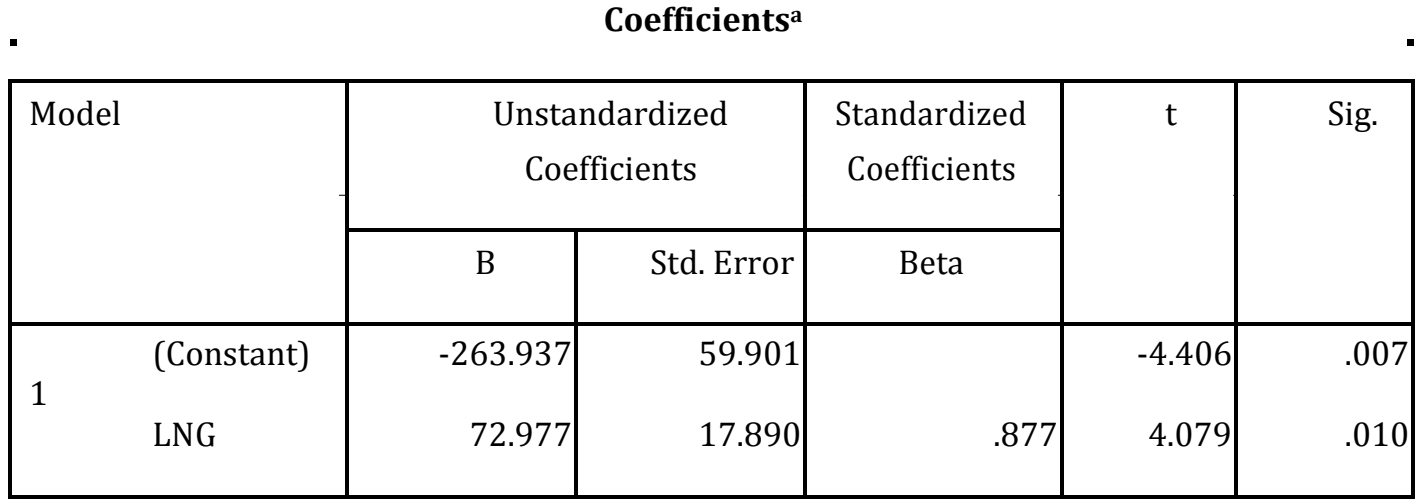

a. Criterion variable: ATP

Table 1 above shows that the value of $\mathrm{R} 2=$ 0.769 was revealed by the model and the adjusted R2 value is 0.723 , suggesting that the model explains about 77 percent of the criterion variable's systemic variations. This implies that 77 per cent of the variance in the data is explained by regression.

Table 2 shows that the F-stat (16.641) and pvalue $(0.010)$ indicate that the hypothesis is statistically significant and that the implication of the alternative hypothesis between dependent and predictor variables can not be rejected at the level of 5 percent.

In table 3, the result of the regressed correlation coefficient shows that an evaluation of the predictor variable's financial success (Beta Column) shows that the perspective of Growth and Learning is positive and significant (Sig.= .007). Therefore, the perspective of Growth and Learning has a major impact on firm's success using the after tax profits of small and medium-sized enterprises in Port Harcourt, Rivers State. In this context, we reject alternative hypotheses and accept null hypotheses stating that the perspective of Growth and Learning does not affect the after tax profits of small and medium-sized enterprises in Port Harcourt, Rivers State.

\section{Hypothesis Two}

Ho: Consumer Perspective does not affect after tax profits of small and medium scale enterprises in Port Harcourt, Rivers State.

Table 4: Model Summary

\begin{tabular}{|l|r|r|r|r|}
\hline Model & \multicolumn{1}{|c|}{ R } & R Square & \multicolumn{1}{c|}{$\begin{array}{c}\text { Adjusted R } \\
\text { Square }\end{array}$} & $\begin{array}{c}\text { Std. Error of } \\
\text { the Estimate }\end{array}$ \\
\hline 1 & $.867^{\mathrm{a}}$ & .752 & .702 & 22.57424 \\
\hline
\end{tabular}

a. Predictors: (Constant), CUSPERS

Table 5: ANOVA ${ }^{\mathrm{a}}$

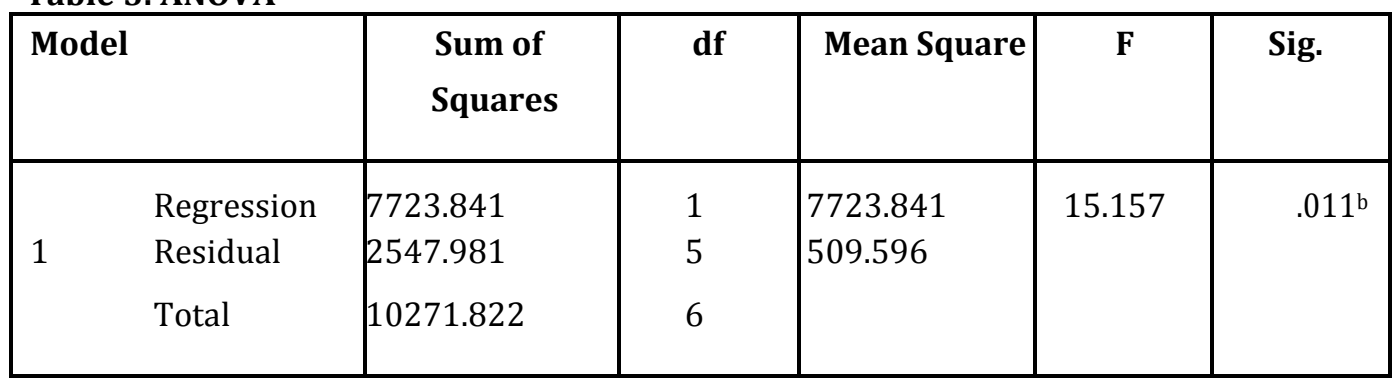

a. Criterion variable: ATP 


\section{EPRA International Journal of Research and Development (IJRD) \\ Volume: 5 | Issue: 10 | October 2020

b. Predictors: (Constant), CUSPERS

Table 6: Coefficients ${ }^{a}$

\begin{tabular}{|c|c|c|c|c|c|}
\hline \multirow[t]{2}{*}{ Model } & \multicolumn{2}{|c|}{$\begin{array}{l}\text { Unstandardized } \\
\text { Coefficients }\end{array}$} & \multirow{2}{*}{$\begin{array}{c}\text { Standardized } \\
\text { Coefficients }\end{array}$} & \multirow[t]{2}{*}{$\mathbf{t}$} & \multirow[t]{2}{*}{ Sig. } \\
\hline & B & Std. Error & & & \\
\hline $\begin{array}{l}\text { (Constant) } \\
\text { BPPERS }\end{array}$ & $\begin{array}{l}153.729 \\
-1.935 \mathrm{E}-007\end{array}$ & $\begin{array}{l}45.913 \\
.000\end{array}$ & -.867 & $\begin{array}{l}3.348 \\
-3.893\end{array}$ & $\begin{array}{l}020 \\
011\end{array}$ \\
\hline
\end{tabular}

a. Criterion variable: ATP

Table 4 above shows that the value of $\mathrm{R} 2=$ 0.752 was revealed by the model and the adjusted R2 value is .702, suggesting that the model explains about 75 percent of the criterion variable's systemic variations. This implies that 75 per cent of the variance in the data is explained by regression.

Table 5 shows that the F-stat (15.157) and pvalue $(0.011)$ indicate that the hypothesis is statistically significant and that the implication between dependent and predictor variables cannot be rejected at the $5 \%$ level of the alternative hypothesis.

In table 6 , the result of the regressed correlation coefficient shows that an evaluation of the predictor variable's financial success (Beta Column) shows that the consumer perspective is positive and significant
$($ Sig. $=0.020)$. Therefore, the consumer perspective has a significant implication on the firm's success of small and medium-sized businesses in Port Harcourt, Rivers State, using after tax profits. In this context, we reject the null hypothesis and accept the alternative hypothesis that states that the consumer perspective affects the return on small and medium-sized business assets in Port Harcourt, Rivers State.

\section{Hypothesis Three}

Ho: Company's Business Process Perspective does not affect after tax profits of small and medium scale enterprises in Port Harcourt, Rivers State.

Table 7: Model Summary

\begin{tabular}{|l|r|r|c|c|}
\hline Model & \multicolumn{1}{|c|}{ R } & R Square & $\begin{array}{c}\text { Adjusted R } \\
\text { Square }\end{array}$ & $\begin{array}{c}\text { Std. Error of } \\
\text { the Estimate }\end{array}$ \\
\hline 1 & $.448^{\mathrm{a}}$ & .201 & .041 & 40.51312 \\
\hline
\end{tabular}

a. Predictors: (Constant), BPPERS 
Table 8: ANOVA ${ }^{\mathrm{a}}$

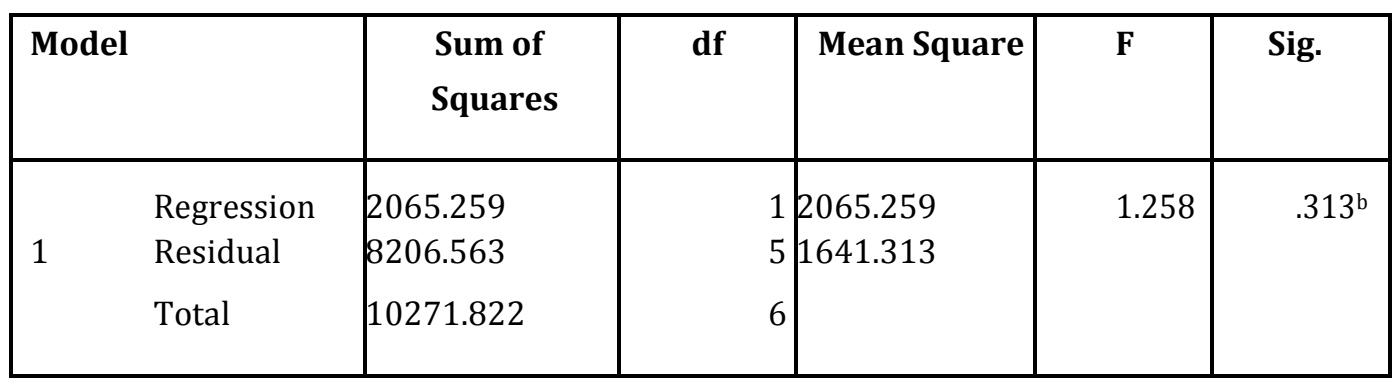

a. Criterion variable: ATP

b. Predictors: (Constant), BPPERS

Table 9: Coefficients ${ }^{\mathrm{a}}$

\begin{tabular}{|c|c|c|c|c|c|}
\hline \multirow[t]{2}{*}{ Model } & \multicolumn{2}{|c|}{$\begin{array}{l}\text { Unstandardized } \\
\text { Coefficients }\end{array}$} & \multirow{2}{*}{$\begin{array}{c}\begin{array}{c}\text { Standardized } \\
\text { Coefficients }\end{array} \\
\text { Beta }\end{array}$} & \multirow[t]{2}{*}{$\mathbf{t}$} & \multirow[t]{2}{*}{ Sig. } \\
\hline & B & Std. Error & & & \\
\hline (Constant) & -135.394 & 102.326 & & -1.323 & .243 \\
\hline BPPERS & 7.080 & 6.312 & .448 & 1.122 & .313 \\
\hline
\end{tabular}

\section{a. Criterion variable: ATP}

Table 7 above shows that the value of $\mathrm{R} 2=0.201$ was revealed by the model and the adjusted R2 value is .041 , which indicates that the model explains about 20 percent of the criterion variable's systemic variations. This implies that 20 per cent of the variance in the data is explained by regression.

Table 8 shows that the F-stat (1.258) and pvalue (0.313) indicate that the hypothesis is statistically significant and that the implication between dependent and predictor variables can not be rejected at the $5 \%$ level of the alternative hypothesis.

In table 9, the result of the regressed correlation coefficient shows that an assessment of the financial success of the predictor variable (Beta Column) shows that the perspective of the business process is positive and significant $(\mathrm{Sig} .=0.448)$. Therefore, consumer perspective has a major impact on the firm's success of the Business Process Perspective goods small and medium scale firms in Nigeria using after tax profits. In this context, we reject the null hypothesis and accept the alternative hypothesis that Business Process Perspective affects the after tax profits of small and medium-sized firms in Port Harcourt, Rivers State..

\section{Discussion of Findings}

The study found that the perspective of Growth and Learning affects the after tax profits of small and medium-sized enterprises in Port Harcourt, Rivers State, while the view of consumers and the business process perspective of firms affects the after tax profits of small and medium-sized enterprises in Port Harcourt, Rivers State. In the meantime, the dependent (after tax profits) and predictor variables (learning, consumer and business process perspectives) are significantly significant.

This outcome is in line with the following studies; evidence from Dutch firms by Braam and Nijssen (2008) suggests that the use of BSC will not automatically improve the success of the company, but that it matters how it is used. The results of Noor, Mseden and Mohammad (2015) stipulate that each of 


\section{EPRA International Journal of Research and Development (IJRD)}

the balanced dimensions of the scorecards (internal business processes, innovation and growth and consumer) has a significant positive impact on the ATP and ROE financial success drivers. Research by Arben, Skender Arbana and Muhamet (2016) concludes that a balanced scorecard has helped improve the efficiency and profitability of the firms that have adopted the model. The study results from Lasisi, Olajide, Hasan, \& Shodiya (2014) confirm that there is a statistically significant relationship in Nigerian small and medium scale firms between relational capabilities and balanced scorecard.

\section{CONCLUSION AND RECOMMENDATIONS}

The study found that in Port Harcourt, Rivers State, the financial perspective does not affect the after tax profits of small and medium-sized enterprises, while the consumer perspective and the business process perspective of the company affect the after tax profits of small and medium-sized enterprises in Port Harcourt, Rivers State. In the meantime, the dependent (after tax profits) and predictor variables (Growth and Learning, consumer and business process perspectives) have a statistically significant effect. This shows that firms fulfill the expectations of their shareholders, delight their consumers, or at least satisfy them, and that firms do the right things.

Despite the opposing views of supporters and critics of the use of the balance scorecard, it is important to note that the model is a generally acceptable success measurement framework, as it points out that the two financial and non-financial success measurements translate a business strategy into operational terms. On the basis of the results of the empirical studies and the analysis carried out, the balanced scorecard has conclusively contributed to improving the success of firms that have adopted the model.

\section{Recommendations}

The study made the following recommendations, based on the findings:

1. In order to make it profitable, small and medium scale firms in Nigeria should consider the issue of production costs and must improve their cost minimization strategy.

2. In order to make them feel cherished, consumers need to be more involved in decision-making and continue to provide the firm with business instead of competition.

3. In order to aim for financial sustainability and see how to improve human resource management, the strategic plan must be reviewed.

\section{REFERENCE}

1. Abernathy,W.B.(2000).Managing without supervising: Creating an firm-wide success system Memphis, TN: William B. Abernathy

2. Akram, R. \& Tariq, D. (2014). Adoption of balanced scorecard (BSC) in Palestinian Corporations. Sci-Afric Journal of Scientific Issues, Research and Essays Vol. 2 (5), Pp. 193-203, May, 2014. (ISSN 2311-6188) http://www.sciafricpublishers. org

3. Atkinson, A.A. \& Kaplan, R. S. (2003) Management accounting, prentice - Hall of India, New Delhi, 3rd Ed.)

4. Arben, S., Skender, A., Arbana, S. \& Muhamet, A. (2016).The impact of balanced scorecard on improving the success and profitability of the implementing firms. Mediterranean Journal of Social Sciences,MCSER Publishing, Rome-Italy 7(4).

5. Bassioni, H., Price, A., \& Hassan, T. (2004). "Success Measurement in Construction." J.Manage. Eng., 2(42), 42-50.

6. Bremser, W. G., \& Barsky, N. P. (2004). Utilizing the balanced scorecard for $R \& D$ success measurement. R\&D Management, 34(3), 229- 238.

7. Braam G. J.M. \& Nijssen E. J. (2004). Success effects of using the Balanced Scorecard: a note on the Dutch experience. LRP long range planning www.lrpjournal.com

8. Chaudron, D. (2003). The balanced scorecard \& success improvement: Available from http://www.organizedchange.com/balancedscoreca rd.htm [Accessed: 12 May, 2008].

9. Chabrow, E. (2002). Keep' em happy. Information Week, September 23 907, 20-22.

10. Christesen, D. A. (2008). The impact of balanced scorecard usage on firm success.ProQuest.

11. Chytas, P. (2011). A proactive balanced scorecard. In: International Journal of Information Management (pp. 460 - 468). ISSN 0268-4012.

12. DavisS. \& Albright T. (2004). An investigation of the implication of balanced scorecard implementation organisational success, Management accounting research, Vol. 15, pp.135153.

13. Frigo, M. L. \& Krumwiede, K. R. (2000). The balanced scorecard Strategic Finance, 81, 50-54. Gekonge, C. O. (2005). What a System!" The Professional Journal of KASNEB, Issue No. 4. Hoque, Z. \& James, W. (2000). Linking balanced scorecard measures to size and market factors:impact on firm's success, Journal of Management Accounting Research, 12, 1-17.

14. Iselin, E. R., Mia, L., \& Sands, J. (2008). The effects of the balanced scorecard on success: The impact of the alignment of the strategic goals and success reporting. Journal of General Management, 33(4). 


\section{SJIF Impact Factor: 7.001| ISI I.F.Value:1.241| Journal DOI: 10.36713/epra2016 ISSN: 2455-7838(Online) EPRA International Journal of Research and Development (IJRD)}

15. Ibrahim, S. \& Upendra, L., (2016). Impact of balanced scorecard implementation organisational success of Saudi listed firms. Journal of Behavioural Economics, Finance, Entrepreneurship, Accounting and Transport, 2016, 4(1) 8-12 Available online at

16. http://pubs.sciepub.com/jbe/4/1/2 (C) Science and Education Publishing DOI:10.12691/jbe-4-1-2.

17. Kaplan, R., \& Norton, D. P. (2015). Balanced Scorecard Success: The Kaplan-Norton Collection (4 Books). Harvard Business Review Press. Retrieved from https://books.google.com/books? hl=en\&lr $=\& i d=0$ $m V h C w A A Q B A J \& o i=$ fnd \& $p g=P T 8 \&$ $\underline{d q=\text { kaplan }+ \text { and }+ \text { norton },+ \text { balance }+ \text { scorecard\&ots }}$ $=C Y v w w E k j 90 \&$ sig $=g 4 \_o 2 T I L d P q A s Z$ I4Jd9_O2gyvZI.

18. Kaplan, R. S. \& Norton, D. P. (1992). Balanced Scorecard: Measures that drive success, Harvard Business Review, 70(1) pp. 71-79.

19. Kassahun, T. (2010). Rethinking institutional excellence in Ethiopia: adapting and adopting the Balanced Scorecard (BSC) model JBAS Vol.2 (1) May pp 22-53.

20. Kairu, E. W., Wafula, M. O. Okaka, O. Odera, O.\& Akerele, E. K. (2013). Effects of balanced scorecard on success of firms in the service sector. European Journal of Business and Management. 5(9). ISSN 2222-1905 (Paper) ISSN 2222-2839 (Online.

21. Kotler, P. \& Armstrong, G. (2004). Principles of Marketing, Prentice - Hall of India, New Delhi, 10th Ed.),

22. Kaplan, R. S., \& Norton, D. P. (2005). The balanced scorecard: measures that drive success. Harvard business review, 83(7), 172.

23. Kairu, E. W., Wafula, M. O., Okaka, O., Odera, O., \& Akerele, E. K. (2013). Effects of balanced scorecard on success of firms in the service sector. European Journal of Business and Management, 5(9), 81-88.

24. Kala, D. \& Bagri S.C. (2014). Balanced scorecard usage and success of Hotels: A Study from the Tourist State of Uttarakhand, India.Asia-Pacific Journal of Innovation in Hospitality and Tourism, Vol. 3(2) pp. 153-173

25. Lasisi, J. O. Olajide, A. R., Hasan, B. \& Shodiya $O$. A. (2014).An exploratory study of relational capabilities and balanced scorecard in the Nigeria. Small and medium scale firms Review of Public Administration and Management, 3, (5), July 2014 ISSN: 2315-7844

26. Malina, M.A., Selto, F.H., (2001). Communicating and controlling strategy: an empirical study of the effectiveness of the Balanced Scorecard. Journal of management accounting research, Vol. 13, pp 4790.

27. Muhammad, A. B. (2010). Corporate success management \& Impact of Balanced Scorecard
System. European Center for Best Practice Management. Research Paper: RP ECBPM/0029.

28. Neely, A. (2008). Does the empirical investigation. https://dspace.lib.cranfield.ac.uk/handle/1826/3932

29. Needleman, T. (2003) Consumer satisfaction is supreme. Internet World, May 9, 6.

30. Noor A., Mseden, A. \& Mohammad A. (2015). The implication of Balanced Scorecard (BSC) implementation on the financial success of the Jordanian firms. Proceedings of 11th International business and social science research conference 8 9 January, Crown Plaza Hotel, Dubai, UAE. ISBN: 978- 1-922069-70-2.

31. Ondieki, E. M. (2017). The implication of the balanced scorecard on firm's success in the public sector in Kenya: a case of Kenya bureau of standards. United States international university.

32. Spraakman, G. (2005) The impact of enterprise resource planning systems on management accounting: some Canadian findings and suggestions for future research.

33. Tayler, W. B. (2007). The Balanced Scorecard as a Strategy-evaluation Tool: The effects of responsibility and a causal-chain focus. Cornell University, Aug. 2007.

34. Zairi, M. \& Jarrar. Y.F. (2000). Internal transfer of best practice for success excellence: a global survey, Benchmarking: An International Journal, 7(4), pp 239-246. 